\title{
MCF を用いた磁場・電場同時印加による精密研磨の電気的特性
}

\section{Electrical Characteristics of Precision Polishing Using Magnetic Compound Fluid While Simultaneously Applying Magnetic and Electrical Fields}

\author{
西田 均*1 (正員)，山本 久嗣*1 (正員)，藤岡 里美*2 \\ 島田 邦雄*3，井門 康司 ${ }^{* 4}$ (正員) \\ Hitoshi NISHIDA (Mem.), Hisashi YAMAMOTO (Mem.), Satomi FUJIOKA \\ Kunio SHIMADA, Yasushi IDO (Mem.)
}

\begin{abstract}
In this study, the relationship between the amount of material removed and the current characteristics on polishing or processing using a magnetic compound fluid (MCF) while simultaneously applying electric and magnetic fields was investigated. Changes in the amount of material removed and the electric current in each experimental condition for flat surface polishing and cylindrical inner surface processing were clarified. It was confirmed that the amount of material removed was increased by the application of an electric field, and that the processed surface was flattened and smoothed when processing the inner surface of the cylinder. The electrical characteristics in each polishing or processing method were considered from the electric current characteristics.
\end{abstract}

Keywords: magnetic compound fluid, precision processing, magnetic field, electric field, electrical characteristics.

(2020 年 5 月 20 日受付, 2021 年 1 月 7 日再受付)

\section{1 緒言}

現在，高硬度材料や難削材料の研磨加工では加工能 率と研磨後の形状精度の変化が課題になっている。こ れに対して著者らは磁気混合流体(MCF)を用いた平面 や円筒内面などに対する研磨法を開発して, 研磨原理 と研磨特性を明らかにするとともに，加工能率と形状 精度について調べている $[1,2]$ 。MCF を用いた研磨 (MCF 研磨)では加工面の平滑化と同時に形状精度を保 持する精密仕上げが可能である。しかし，MCF 研磨は 高硬度材料に対して加工能率が低いという課題がある。 このような状況下で, MCF が静止状態において非導 電性流体であることが判明し，電気粘性流体効果(ER 効果)を有する可能性があることがわかった。すなわち, ER 効果により, MCF の見かけの粘度が増加する, あ るいは，誘電体である砥粒が加工表面に付着すること で加工能率の向上が期待できる[3]。

そこで，本研究では平面と円筒内面に対して，MCF に磁場に加え電場を印加する研磨加工法を提案して, それぞれの加工特性と電気的特性について明らかにす

連絡先 : 西田 均, $\bar{\top} 939-8630$ 富山市本郷町 13, 富山高等 専門学校電気制御システム工学科,

e-mail: nishida@nc-toyama.ac.jp

*1 富山高等専門学校 *2 株式会社フェローテック

*3福島大学 *4 名古屋工業大学
ることを目的とする。具体的には，磁場に加え電場を 印加した場合の加工量特性と表面性状，電流特性を調 べ，加工に及ぼす電場の効果を明らかにする。また， 加工量と電流特性に及ぼす電場の種類や工具構造, 砥 粒の材質などの影響を調べる。

\section{2 研磨加工方法}

平面研磨と円筒内面加工の模式図を Fig. 1 と Fig. 2 にそれぞれ示す。工具は平面研磨では円柱状の永久磁 石である。円筒内面加工ではリング状永久磁石を用い てスペーサを挟んで積層したものである。MCF に磁場 を印加すると磁力線方向に磁性体分散粒子で構成され る凝集体(磁気クラスタ)が形成される。平面研磨での 磁気クラスタは磁力線方向に形成され，加工表面に対 してほぼ垂直に作用寸る。研磨は砥粒に磁気クラスタ の加工力が作用すること砥粒と加工表面の相対運動に よって行われる。円筒内面加工ではリング状永久磁石 の外周面に管軸方向に形成された磁気クラスタが加工 表面に平行に作用する。加工は砥粒に平行磁気クラス タの半径方向の加工力が作用すること砥粒と加工表面 の相対運動によって行われる。電場印加のために電源 の電極は一方が永久磁石に他方が加工物に接続されて いる。これにより，電気力線は平面研磨では磁気クラ スタとほぼ平行になる。一方, 円筒内面加工での電気 


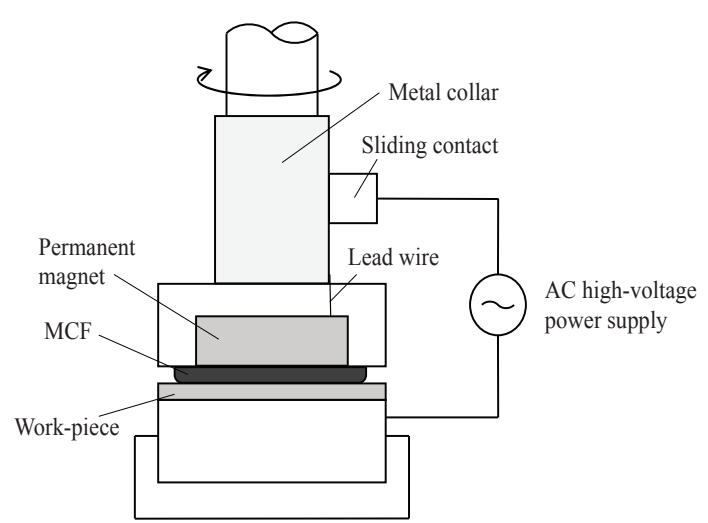

Fig.1 Schematic diagram for surface polishing.

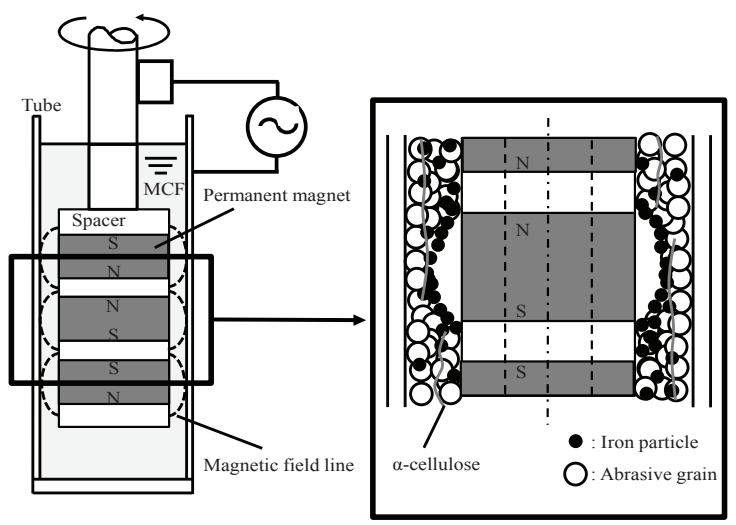

Fig.2 Schematic diagram for inner surface processing.

力線はリング状永久磁石の外周面から加工面に向かっ て放射状になり, 電気力線と磁気クラスタは交差する。

\section{3 実験装置}

Fig. 3 に平面研磨実験装置の外観を示す。実験装置 は磁気研磨装置(3D-MNPS I, FDK 株式会社製) を改 造したもので，上部の研磨工具部と下部のワーク固定 部で構成されている。Table 1 に研磨工具の諸言を示す。 研磨工具は樹脂製の本体とステンレス鋼製のカラー, 円柱形永久磁石で構成されている。永久磁石には表面 をニッケルメッキで覆ったネオジム磁石 $\left(\mathrm{Nd}_{2} \mathrm{Fe}_{14} \mathrm{~B}\right.$, N52)を用いた。Table 2 に使用した MCF 加工液の成分 を示す。加工物(ワーク)はステンレス鋼製の円板(直径 $30 \mathrm{~mm}$, 厚さ $2 \mathrm{~mm}, \mathrm{SUS} 304-2 \mathrm{~B})$ を用いた。ワーク表面 の初期算術平均粗さ $R a_{0}$ の平均值は $0.154 \mu \mathrm{m}$ である。 研磨実験では工具先端とワークの隙間間隔 $\delta=1.0 \mathrm{~mm}$ とし, 工具回転数 $n=500 \mathrm{rpm}$, 研磨時間 $t=40 \mathrm{~min}$ と した。また, 印加電場強度 $E$ は, $E=0,250,500 \mathrm{~V} / \mathrm{mm}$ の 3 種類とし, 研磨実験ごとに $0.63 \mathrm{~mL}$ の MCF 加工 液を使用した。

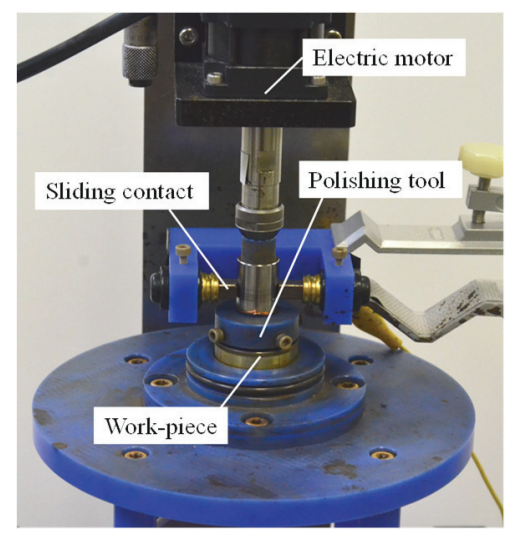

Fig.3 Experimental setup for surface polishing.

Table 1 Specifications of polishing tool

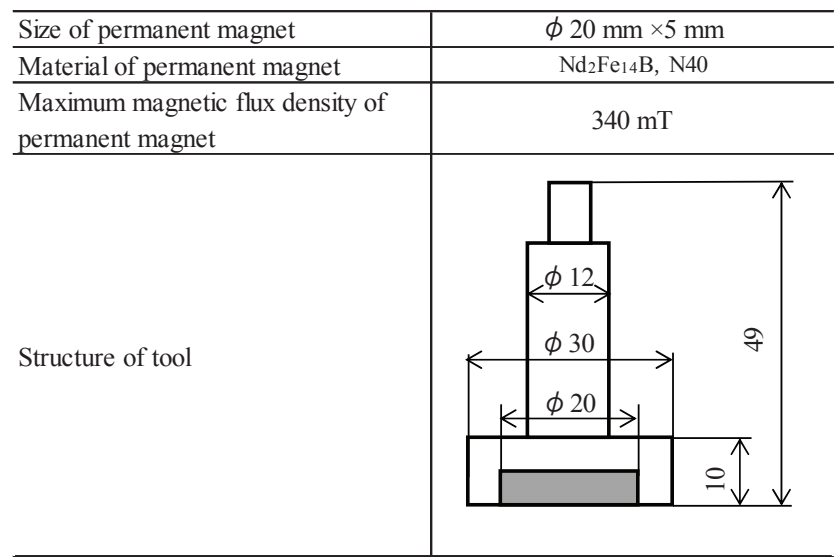

Table 2 Components of MCF processing fluid.

\begin{tabular}{|c|c|}
\hline MF (MSGS60) & 39.2 wt. $\%$ \\
\hline Iron powder $(1.2 \mu \mathrm{m}, \mathrm{HQ})$ & 30.4 wt. $\%$ \\
\hline $\mathrm{Al}_{2} \mathrm{O}_{3}$ abrasive $(3 \mu \mathrm{m})$ & 20.0 wt. $\%$ \\
\hline$\alpha$-cellulose & 6.4 wt. $\%$ \\
\hline Kerosene & 4.0 wt. $\%$ \\
\hline
\end{tabular}

Fig.4 に円筒内面加工実験装置の外観を示す。装置 は垂直に固定された電動スライダのテーブルに直列に 設置された ACサーボモータ，トルク計 (MD-503C，小 野測器), 工具から成る上部機構と円筒状の加工物（ワ 一ク）を固定するステージ部で構成されている。ワー クはステンレス鋼製円管(SUS304BA)であり，寸法は内 径 $23.9 \mathrm{~mm}$, 外径 $27.2 \mathrm{~mm}$, 長さ $150 \mathrm{~mm}$ である。ワ 一ク内面の初期算術平均粗さ $R a_{0}$ の平均值は $0.315 \mu \mathrm{m}$ である。本研究で開発した 4 種類の工具の諸元を Table 3 に示す。工具は3 個のリング状の永久磁石を使用し, スペーサを挟んで同極が向かい合うように積層したも のである。永久磁石にはサマリウムコバルト磁石 $\left(\mathrm{Sm}_{2} \mathrm{Co}_{17}, \mathrm{SS} 28\right)$ を用いた。また, スペーサはステンレス 鋼製と MCナイロン製の 2 種類を用いた. Type A は磁 


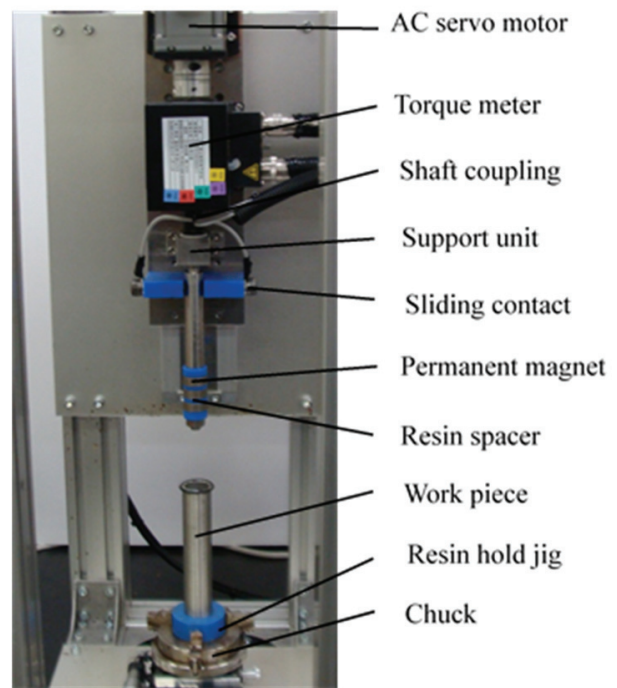

Fig. 4 Experimental setup for inner surface processing.

Table 3 Specifications of processing tools.

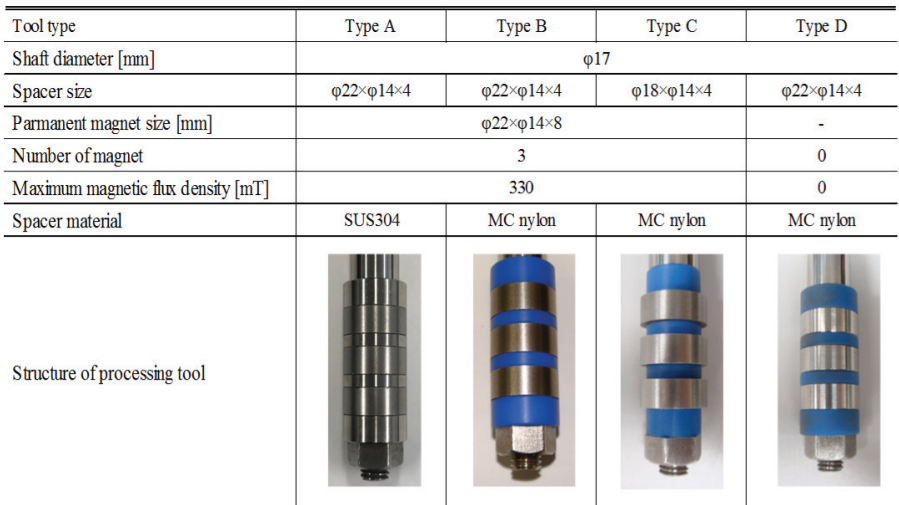

場印加のみの実験に使用し, Type B は磁場に加え電場 を印加した場合の実験で使用した。また，Type C は小 径のスペーサにより Type B より多くの加工液が保持 できる工具である。また, Type D はリング状永久磁石 の代わりに同じサイズの SUS304 製リングを用いたも ので，電場のみ印加できる工具である。

\section{4 平面研磨の実験結果}

\section{1 加工量と電流特性}

Fig. 5 に印加電場ごとの加工量 $M$ と加工時間 $t$ の関係 を示す。無電場の場合, $t=30 \mathrm{~min}$ で飽和することがわ かる。 $E=250 \mathrm{~V} / \mathrm{mm}$ の場合も加工量は無電場の場合と ほとんど変わらない。しかし， $E=500 \mathrm{~V} / \mathrm{mm}$ を印加し た場合, $t=30 \mathrm{~min}$ 以上でも加工量が増加する傾向を示 している。 $E=0 \mathrm{~V} / \mathrm{mm}, 250 \mathrm{~V} / \mathrm{mm}$ では $t=30 \mathrm{~min}$ を過 ぎると砥粒が研磨面に作用していないと考えられる。 $E=250 \mathrm{~V} / \mathrm{mm}$ で電場の効果が確認できなかったのは
電場強度が小さいためと考えられる。一方， $E=500$ $\mathrm{V} / \mathrm{mm}$ では電場の効果により, 砥粒が研磨面に配置さ れていると考えられる。なお，砥粒の電気泳動の可能

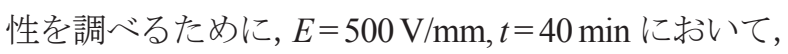
永久磁石工具をマイナス側電極，加工物をプラス側電 極にして加工実験を行った。実験の結果，加工量が同 じであったことから, 砥粒の電気泳動の可能性は低い と考えられる。

Fig. 6 に無電場と $E=500 \mathrm{~V} / \mathrm{mm}$ の場合の加工前後の 断面曲線をそれぞれ示す。加工領域は磁場のみの場合, 半径方向に 2 ケ所存在する。これは，永久磁石角部の

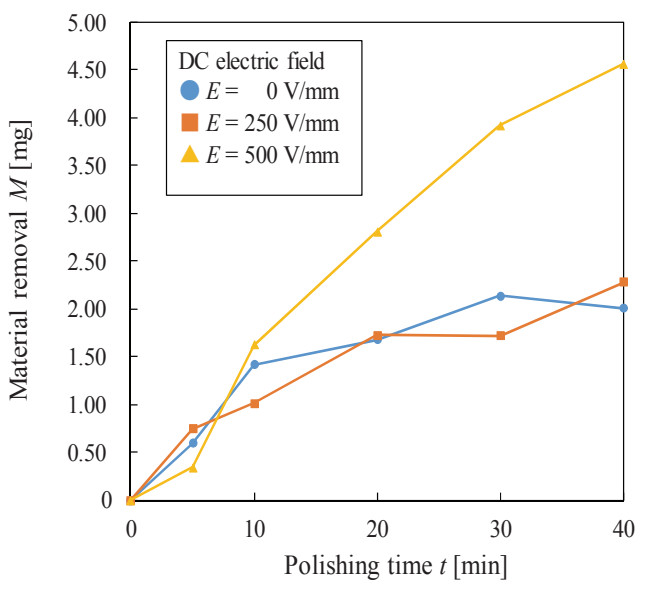

Fig. 5 Relationship between material removal and polishing time.

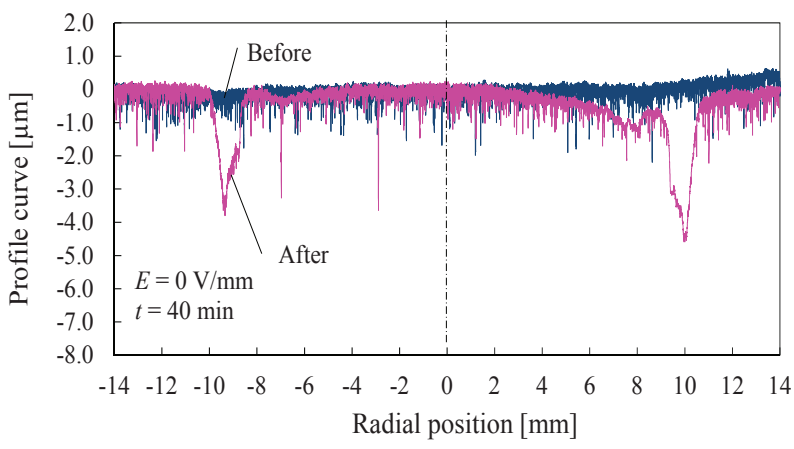

(a) $E=0 \mathrm{~V} / \mathrm{mm}$

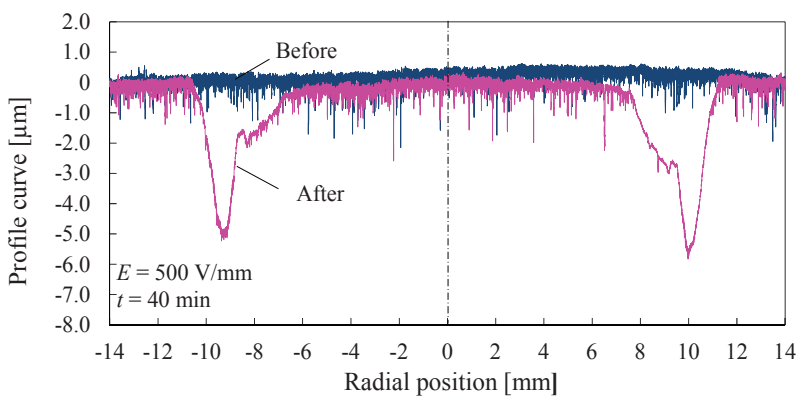

(b) $E=500 \mathrm{~V} / \mathrm{mm}$

Fig. 6 Profile curves of polished surface. 
$r=10 \mathrm{~mm}$ 前後における比較的太い磁気クラスタとそ の内側の $r=7 \sim 8 \mathrm{~mm}$ 付近の磁気クラスタの分布が反 映されたものと考えられる。一方，電場を加えた場合 では, $r=6 \mathrm{~mm} \sim 10 \mathrm{~mm}$ の広い範囲の 1 ケ所である。 また, 研磨後の加工表面については大きな違いは見ら れず，それぞれ平滑化された。

Fig. 7 に $E=500 \mathrm{~V} / \mathrm{mm}$ の場合の電流 $I$ の時間的変化 を示す。電場印加後, 電流はいったん減少するものの, その後は増加を続けることがわかる。すなわち, MCF の電気抵抗が小さくなっていくことがわかる。平面研 磨の直流磁場ではワークに作用する軸力が時間ととも に増加して定常状態になる。これは磁場印加後, 回転 流れにより磁気クラスタの破断と凝集が繰り返され, 時間の経過とともに太い磁気クラスタを形成するため と考えられる[4]。電流の多くは磁気クラスタを通して 流れると考えられるので, 電流の増加は時間的に磁気 クラスタの断面積が増加するためと考えられる。すな わち, 電流の時間的変化は磁気クラスタの構造の時間 的変化によるものと考えられる。

\section{2 印加電場の種類と砥粒の影響}

印加電場の種類と砥粒の材質の影響を調べた実験 条件(実験 $\mathrm{C}$ 実験 F)を Table 4 に示す。また, この場 合の加工量を Fig. 8 に示寸。加工量は交流電場の方が パルス電場より大きい。交流電場は矩形波であり，パ ルス電場のパルス波の Duty 比は 0.5 である。このこと から，常に電場の印加を続ける方が加工量は大きくな ることがわかる。電場の印加時間の長い方が, MCF 加 工液の粘度, あるいは, 砥粒の加工表面への配置の影 響があると考えられる。次に砥粒にホワイトアランダ ム(WA)より誘電率の大きいに緑色炭化ケイ素(GC)を 用いた場合では，WA の場合と同様に電場印加により 加工量が 2 倍以上増加する。ここで, WA の比誘電率 は 8.5 であり, GC の比誘電率は 9 10 である。また, 磁性流体の母液の比誘電率は 1.8 である。 $\mathrm{GC}$ 砥粒の場 合，加工量が多くなった原因としては誘電率が大きい ために見かけの粘度が大きくなり, 加工液のせん断応 力がより大きくなったためと考えられる。

電流の時間的変化を Fig. 9 に示寸。電流は交流電場 加の方が直流電場より少し大きいものの, 時間的な増 加傾向は同じである。パルス電場の電流は直流電場の 50\%程度であるが，増加傾向は同じである。パルス電 場では直流電場の $50 \%$ の時間に電場印加されるため と考えられる。砥粒に GC を用いて直流電場を印加し

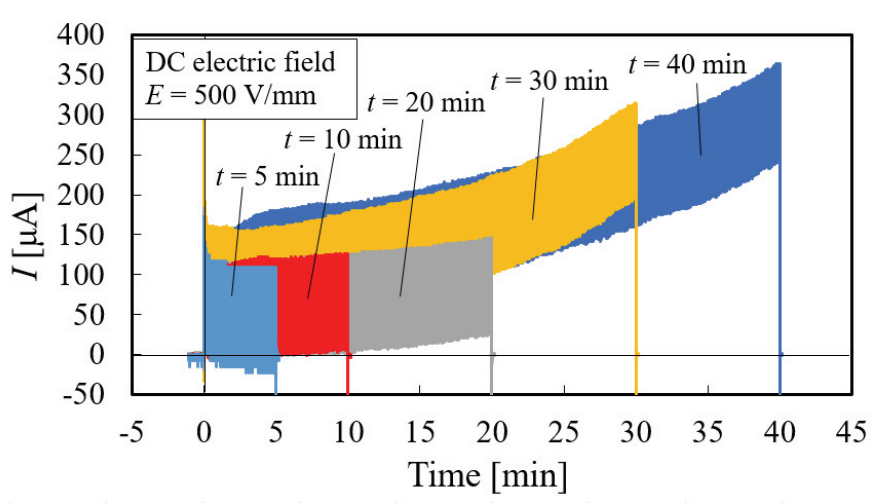

Fig. 7 Change of current with time $(E=500 \mathrm{~V} / \mathrm{mm})$.

Table 4 Experimental conditions for surface polishing.

\begin{tabular}{|c|c|c|c|c|}
\hline $\begin{array}{l}\text { Symbol of } \\
\text { experiment }\end{array}$ & $\begin{array}{l}\text { Polishing time } t \\
\text { [min] }\end{array}$ & $\begin{array}{c}\text { Strength of } \\
\text { electric field } E \\
{[\mathrm{~V} / \mathrm{mm}]}\end{array}$ & $\begin{array}{c}\text { Type of electric } \\
\text { field }\end{array}$ & Abrasive grain \\
\hline A & \multirow{6}{*}{40} & 0 & - & \multirow{4}{*}{ WA } \\
\hline $\mathrm{B}$ & & \multirow{3}{*}{500} & DC & \\
\hline $\mathrm{C}$ & & & $\mathrm{AC}(f=0.1 \mathrm{~Hz})$ & \\
\hline $\mathrm{D}$ & & & Pulse $(f=0.1 \mathrm{~Hz})$ & \\
\hline $\mathrm{E}$ & & 0 & - & \multirow{2}{*}{ GC } \\
\hline $\mathrm{F}$ & & 500 & $\mathrm{DC}$ & \\
\hline
\end{tabular}

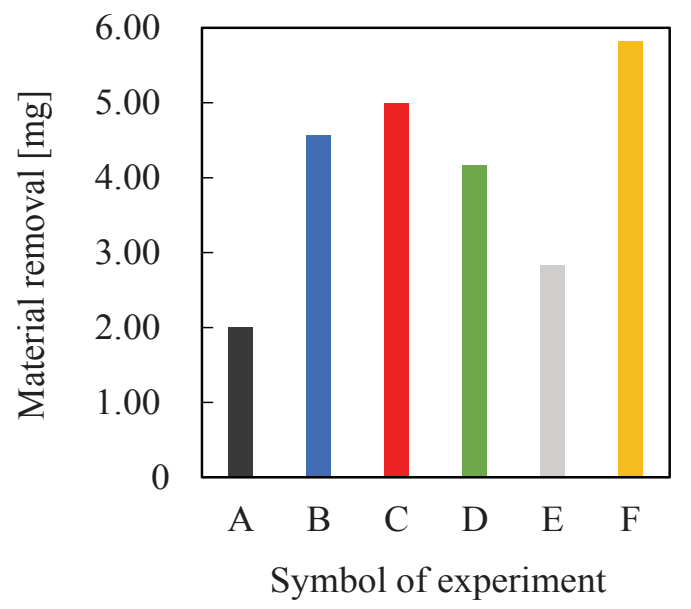

Fig. 8 Material removal under each experimental condition.

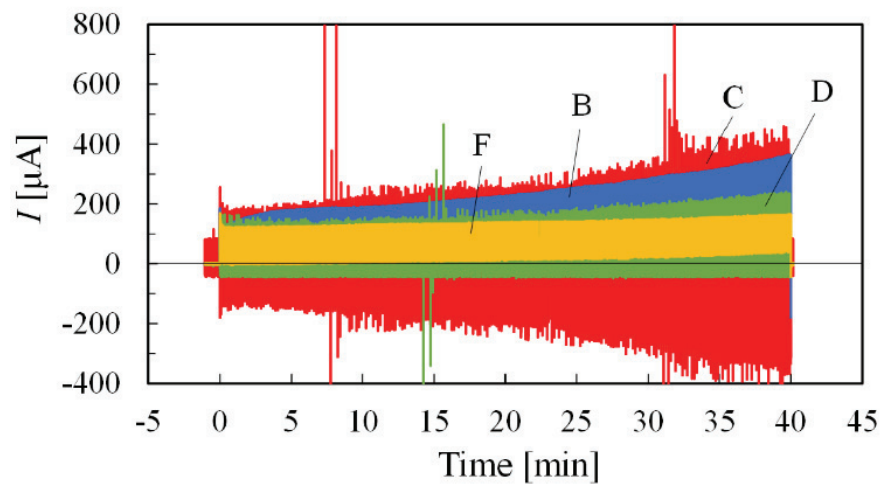

Fig. 9 Change of current with time under each experimental condition. 
た場合の電流值は一番小さく, 時間的な変化も見られ ない。GC 砥粒では電流の増加を引き起こさないこと がわかる。GC 砥粒で電流の増加が起こらない原因と して, 誘電率の大きい $\mathrm{GC}$ 砥粒がワーク表面に多く付 着するため, 磁気クラスタと研磨面の間で電流を流し にくくしていることが考えられる。

\section{5 円筒内面加工の実験結果}

\section{1 加工量と電流特性}

Fig. 10 に加工能率 $M /(A L)$ と工具回転数 $n$ の関係を示 す。本研究では加工能率を単位研磨面積・単位加工距 離あたりの加工量とする。ここで， $A$ は加工面積 $(=$ $\left.3^{*} \pi d_{\mathrm{w}} l\right), L$ は加工距離 $\left(=\pi d_{\mathrm{m}} n\right)$ である。また， $d_{\mathrm{w}}$ はり 一クの内径, $l$ はリング状永久磁石の軸方向の長さ, $d_{\mathrm{m}}$ は永久磁石の直径である。また，Table 5 にそれぞれの 実験条件による加工時間を示す。各実験は電流が 10 $\mathrm{mA}$ を超えたところで停止した。平面研磨では加工面

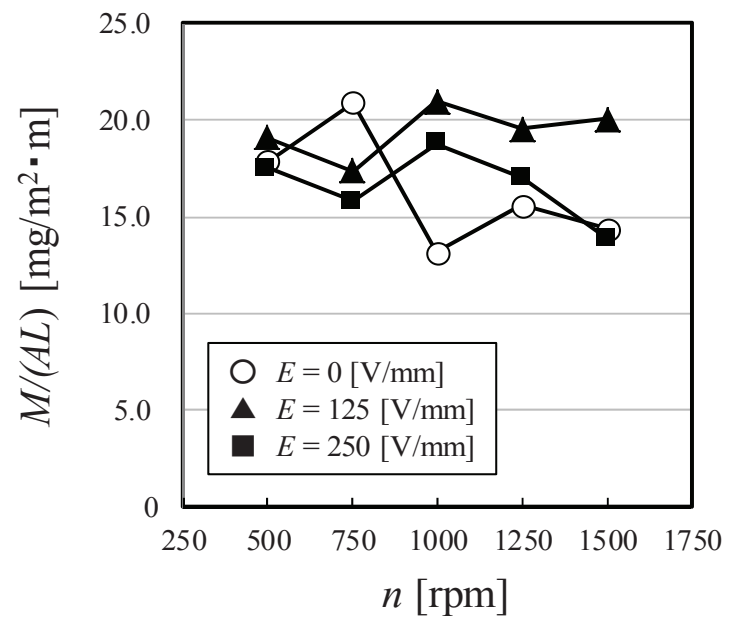

Fig. 10 Relationship between processing efficiency and tool number of revolution.

Table 5 Processing time under each experimental condition.

\begin{tabular}{c|c|c}
\hline \hline $\mathrm{E}[\mathrm{V} / \mathrm{mm}]$ & $n[\mathrm{rpm}]$ & Processing time $[\mathrm{min}]$ \\
\hline \multirow{4}{*}{125} & 500 & 8.38 \\
\cline { 2 - 3 } & 750 & 10.75 \\
\cline { 2 - 3 } & 1000 & 12.58 \\
\cline { 2 - 3 } & 1250 & 8.37 \\
\cline { 2 - 3 } & 1500 & 7.62 \\
\hline \multirow{4}{*}{250} & 500 & 9.33 \\
\cline { 2 - 3 } & 750 & 20.00 \\
\cline { 2 - 3 } & 1000 & 10.67 \\
\cline { 2 - 3 } & 1250 & 7.67 \\
\cline { 2 - 3 } & 1500 & 15.58 \\
\hline
\end{tabular}

に対して垂直に近い磁気クラスタ(以下, 垂直磁気クラ スタと呼ぶ)が作用する。一方，円筒内面加工では加工 面に対して平行に近い磁気クラスタ(以下, 平行磁気ク ラスタと呼ぶ)が作用する。円筒内面加工において， $E$ $=500 \mathrm{~V} / \mathrm{mm}$ の電場を印加した場合, 電流は短時間で 10 $\mathrm{mA}$ 以上になった。この原因は平行磁気クラスタの加 工面に接触する面積が垂直磁気クラスタのそれよりも 大きく, 電流の流れる方向の磁気クラスタの断面積が 大きいためと考えられる。すなわち，同じ電場強度で も平行磁気クラスタの方が電気抵抗值は小さい。その ため, 円筒内面加工では $E=250 \mathrm{~V} / \mathrm{mm}$ 以下で実験を行 った。Fig. 10 から磁場のみの場合の加工能率は工具回 転数 $n=750 \mathrm{rpm}$ でピークを持つ。この原因は工具回転 数の増加につれ，管軸方向に形成された磁気クラスタ に作用寸る流体抵抗が増加し，ある工具回転数で磁気 クラスタが破断したり，崩れたりするためである[5]。 電場を印加した場合, 加工能率は $n=1000 \mathrm{rpm}$ でピー クを持つ。電場の印加により，磁気クラスタが強固に なったと考えられる。加工能率は電場強度の小さい $E$ $=125 \mathrm{~V} / \mathrm{mm}$ の方が $E=250 \mathrm{~V} / \mathrm{mm}$ より大きい。このこ とから, 最適な電場強度が存在することが示唆される。 $E=125 \mathrm{~V} / \mathrm{mm}$ の場合, 加工能率は $1000 \mathrm{rpm} \leqq n \leqq$ $1500 \mathrm{rpm}$ の広い範囲で高いことがわかる。

Fig. 11 に $E=0 \mathrm{~V} / \mathrm{mm}, n=750 \mathrm{rpm}$ と $E=125 \mathrm{~V} / \mathrm{mm}, n$ $=1000 \mathrm{rpm}$ の場合の加工後の断面曲線をそれぞれ示寸。 図中の灰色部分はリング状永久磁石に対応した領域を 示寸。加工領域は最上段と 2 段目の永久磁石に対応し た領域で行われたことがわかる。 3 段目の永久磁石(最 下段の永久磁石)に対応した領域で加工が行われない のは，工具を円管に挿入するときに工具に付着した MCF 加工液が上部に移動するためである。最上段の加 工領域では電場印加の方が平坦である。また，マイク ロスコープ写真から，加工面は電場印加の方が平滑化 されていることがわかった。

Fig. 12 に $E=125 \mathrm{~V} / \mathrm{mm}$ の場合の電流密度 $i$ と加工距 離 $L$ の関係を示寸。電流密度 $i$ は, $i=I / A$ である。こ こで, $A$ は永久磁石外周面の総面積である。電流 $i$ は $L$ の増加と共に徐々に増加していき, その後, 急激に 上昇して, 導通状態になる。電場印加後の電流の増加 現象は平面研磨と同様である。しかし，その後の急激 な上昇については，電流が磁気クラスタを流れること から，磁気クラスタ同士の急激な付着や結合により太 い磁気クラスタを形成することが考えられる。 


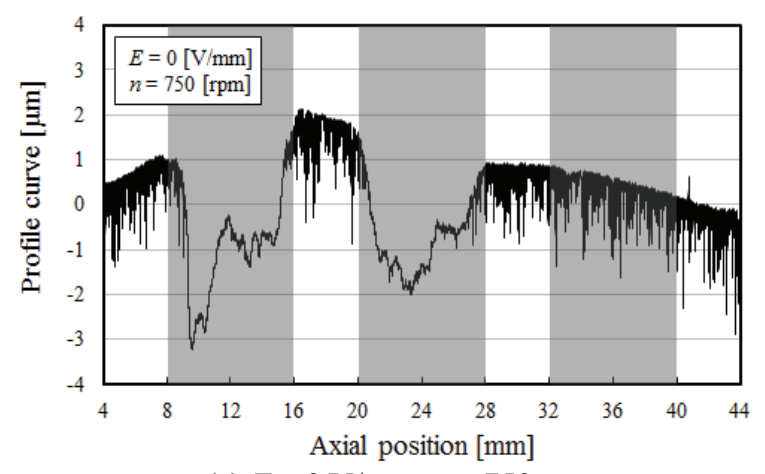

(a) $E=0 \mathrm{~V} / \mathrm{mm}, n=750 \mathrm{rpm}$

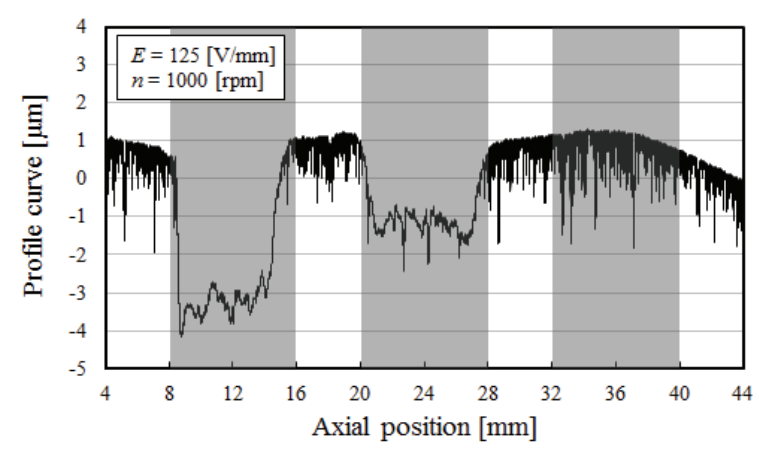

(b) $E=125 \mathrm{~V} / \mathrm{mm}, n=1000 \mathrm{rpm}$

Fig. 11 Profile curves of processed inner surface.

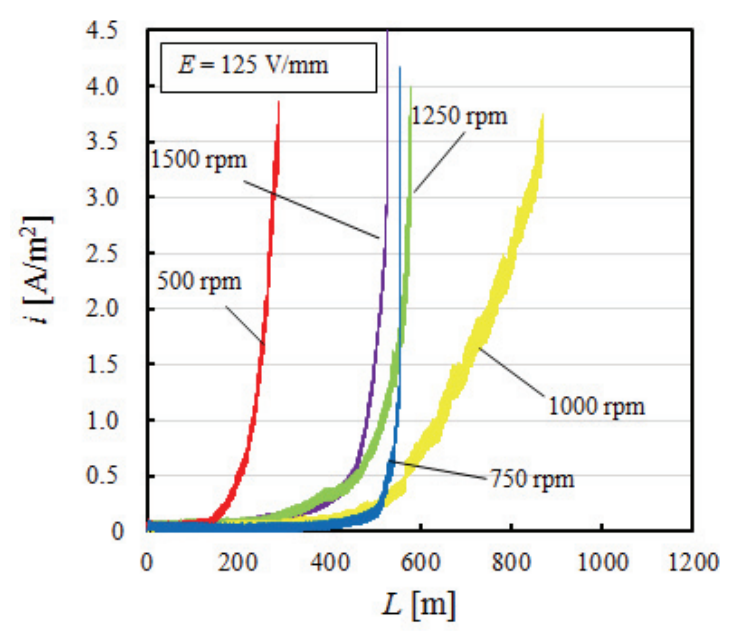

Fig. 12 Change of current with time $(E=125 \mathrm{~V} / \mathrm{mm})$.

\section{2 流体量や工具形状などの影響}

流体量や工具形状，電場の種類，砥粒の材質の影響 を調べた実験条件(実験 D〜実験 G)を Table 6 に示す。 また, この場合の加工量を Fig 13 に, 加工時間を Table 7 にそれぞれ示す。実験 A と実験 B の加工液の量は工 具の上下, 周囲に厚さ $1 \mathrm{~mm}$ 分を付着した量である。 実験 $\mathrm{C}$ は工具が入った底の付いた円管内が加工液で満 たされる加工液量である。実験 D は Type C を使った 場合で, 工具の上下に $1 \mathrm{~mm}$, 工具の外側に直径 $24 \mathrm{~mm}$
Table 6 Experimental conditions for inner surface processing.

\begin{tabular}{c|c|c|c|c|c|c}
\hline $\begin{array}{c}\text { Symbol of } \\
\text { experiment }\end{array}$ & Tool type & $n[\mathrm{rpm}]$ & $\begin{array}{c}\text { Amount of fluid } \\
{[\mathrm{mL}]}\end{array}$ & $\begin{array}{c}\text { Abrasive } \\
\text { grain }\end{array}$ & $\begin{array}{c}\text { Magnetic flux density } \\
B[\mathrm{mT}]\end{array}$ & $\begin{array}{c}\text { Electric field } \\
E[\mathrm{~V} / \mathrm{mm}]\end{array}$ \\
\hline A & Type A & 750 & 4.21 & WA & 330 & 0 \\
\hline B & Type B & 1000 & 4.21 & WA & 330 & 125 \\
\hline C & Type B & 500 & 31.3 & WA & 330 & 125 \\
\hline D & Type C & 1000 & 6.72 & WA & 330 & 125 \\
\hline E & Type D & 1000 & 31.3 & WA & 0 & 125 \\
\hline F & Type B & 1000 & 4.21 & WA & 330 & $\begin{array}{c}125 \\
\text { Pulse } f=0.1 \mathrm{~Hz}\end{array}$ \\
\hline G & Type B & 1000 & 4.21 & GC & 330 & 125 \\
\hline
\end{tabular}

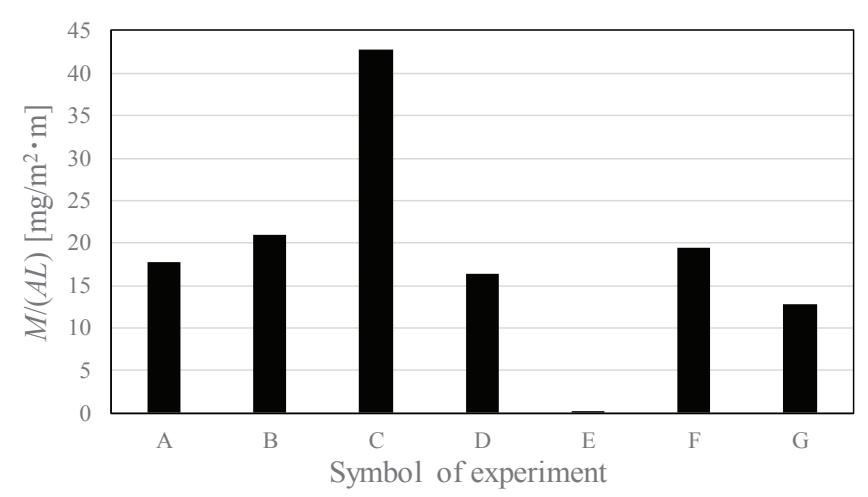

Fig. 13 Material removal under each experimental condition.

Table 7 Processing time under each experimental condition.

\begin{tabular}{c|c}
\hline \hline $\begin{array}{c}\text { Symbol of } \\
\text { experiment }\end{array}$ & $\begin{array}{c}\text { Processing time } \\
t[\mathrm{~min}]\end{array}$ \\
\hline $\mathrm{A}$ & 20.00 \\
\hline $\mathrm{B}$ & 12.58 \\
\hline $\mathrm{C}$ & 10.70 \\
\hline $\mathrm{D}$ & 7.19 \\
\hline $\mathrm{E}$ & 20.00 \\
\hline $\mathrm{F}$ & 11.06 \\
\hline $\mathrm{G}$ & 11.08 \\
\hline
\end{tabular}

の円筒になる加工液量である。Type B に比べて，スペ 一サの直径が小さい分，加工液が多くなる。加工量は $\mathrm{MCF}$ 加工液が多い場合, 寸なわち, 工具が $\mathrm{MCF}$ 加工 液に浸漬した場合に一番多い。これは永久磁石端面近 傍で鉄粉の密度が高くなり太い磁気クラスタを形成し, その結果，加工圧力が大きくなるためと考えられる。 スペーサの直径が永久磁石より小さい Type C の場合, 流体量が Type B より多いにもかかわらず加工量は小 さくなる。これは鉄粉が永久磁石の外周近傍の端面に 多く集まり，管軸方向に形成される磁気クラスタの半 


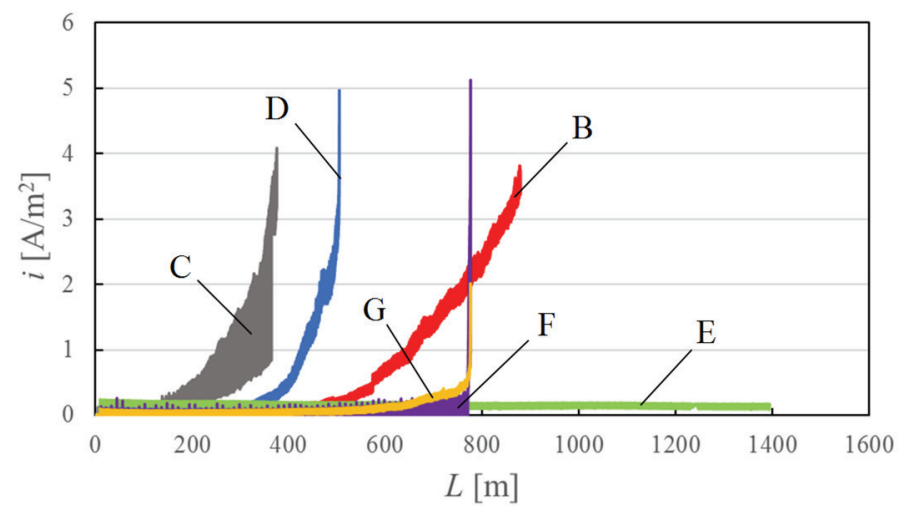

Fig. 14 Change of current with time under each experimental condition.

径方向の加工力が小さくなるためと考えられる。電場 の夕印加した場合では加工はほとんど行われないこと がわかる。また，パルス電場を印加した場合は直流電 場を印加した場合に比べて僅かに少ない。平面研磨に 見られた大きな違いはない，砥粒に GC を使用した場 合, 加工量はWA の場合より小さい。これは平面研磨 と逆の結果である。この原因としては, 円筒内面の場 合, 電場強度が永久磁石外周面の方が加工面より大き いため, 砥粒が永久磁石外周面側により多く付着した ことが考えられる。

電流の時間的変化を Fig. 14 に示寸。電流の変化は工 具が MCF 加工液に浸漬した場合が一番大きい。これ は永久磁石端面近傍で鉄粉の密度が高いために太い磁 気クラスタを形成するため, 電気抵抗が小さくなるた めと考えられる。Type C の場合も同様に永久磁石端面 近傍で鉄粉の密度が高いために電流が流れや寸くなる と考えられる。一方, GC 砥粒の場合, 導通状態に至る までの電流密度の值は小さい。しかし, 実験 B とほぼ 同じ加工時間で導通状態になる。

\section{6 結言}

$\mathrm{MCF}$ に磁場に加え電場を印加する研磨加工法を提 案して, 加工特性と電気的特性を明らかにした。平面 研磨では電場印加により, 加工量が増加するとともに 加工領域も広くなる。円筒内面加工では工具回転数の 広い範囲で加工能率が高くなり, 加工面も平滑化され ることがわかった。

\section{参考文献}

[1] 西田均, 島田邦雄, 井門康司, 磁場制御による磁気混合 流体を用いた平面研磨の基本特性, 実験力学, Vol. 12,
No.4, p. 354, 2012.

[2] 西田均, 島田邦雄, 吉野一郎, 磁気混合流体を用いた円 管内面マイクロ加工の開発研究, 実験力学, Vol. 12, No.4, p. 361, 2012.

[3] 富宇賀健，岡本孝司，斑目春樹，可視化による電気粘性 流体の研究，可視化情報学会誌，Vol.17, p. 229, 1997.

[4] 西田均, 島田邦雄, 井門康司, 百生登, 山本久嗣, 磁場 制御による平面および凹面に対する精密研磨特性, 砥 粒加工学会誌, Vol.61, No.12, p. 666, 2017.

[5] 西田均, 山本久嗣, 百生登, 池田愼治, 島田邦雄, 井門 康司, 磁気混合流体を用いた円筒内面マイクロ加工にお ける加工量特性, 日本 AEM 学会誌, Vol.27, No.3, p. 308, 2019. 